\title{
Monitoring of three Hoplocampa sawfly species in plum orchards
}

\section{Zsolt Kárpáti $^{1 *}$ (), Csengele Bognár ${ }^{1}$ (), Erzsébet Voigt ${ }^{3}$, Miklós Tóth $^{2}$ (1) and Béla Péter Molnár ${ }^{1}$ [C]}

\author{
${ }^{1}$ Zoology Department, Plant Protection Institute, Centre of Agricultural Research, ELRN, Budapest, \\ Hungary \\ ${ }^{2}$ Department of Applied Chemical Ecology, Plant Protection Institute, Centre of Agricultural Research, \\ ELRN, Budapest, Hungary \\ ${ }^{3}$ Independent
}

\section{RESEARCH ARTICLE}

Received:September 21, 2021 • Revised manuscript received: October 19,2021 • Accepted: October 20, 2021 Published online: November 10, 2021

(C) 2021 The Author(s)

\section{ABSTRACT}

Three sawfly species (Hoplocampa minuta, Hoplocampa flava, Hoplocampa fulviicornis) have been monitored in plum orchards during the flowering period in three consecutive years at three different locations in Hungary using chromotropic white sticky traps. Black and yellow sawflies (H. minuta and $H$. flava) are one of the most important pests in plum orchards, however plum-fruit sawfly (Hoplocampa fulvicornis) has not yet been documented from plum orchards in Hungary. In almost all locations and years, H. minuta was the most dominant species, except in Cegléd, 2014, where H. flava was the most abundant one. In terms of sex ratio, in all three species, more males than females were caught in the traps except in 2016 at Érd, where more H. flava females flew into the traps.

\section{KEYWORDS}

Hoplocampa minuta, Hoplocampa flava, Hoplocampa fulvicornis, chromotropic white sticky trap, monitoring

\footnotetext{
*Corresponding author. E-mail: karpati.zsolt@atk.hu
} 


\section{INTRODUCTION}

Black and yellow sawflies (Hoplocampa minuta Christ, 1791 and Hoplocampa flava Linnaeus, 1761), (Hymenoptera: Tenthredinidae) are one of the most dominant pests of plum (Prunus domestica L.) (Rosaceae) in Europe, causing significant damage and yield losses in plum orchards (Caruso and Cera, 2004; Liston et al., 2019; Nagy, 1960). According to our knowledge, Hoplocampa fulvicornis (Panzer, 1801) has not yet been documented as a pest species in plum orchards in Hungary. In other European countries, the primary host plant of this species is the blackthorn (Prunus spinosa L.) (Rosaceae) (Pschorn-Walcher and Altenhofer, 2000); however, this sawfly has also been recorded from cultivated Prunus species (Malenovský, 2012; Roberti, 1948).

H. minuta and $H$. flava are univoltine, monophagous species, often co-occur in plum orchards and feed exclusively on plum fruits. After emerging and mating, during the plum flowering period, the fertilized females insert their eggs into the calix of the flower using their saw-like ovipositor. Parallelly with the fruit development, the larvae hatch and enter into the fruit. One sawfly larva can damage up to 6 fruits, which increases the damage level of these pests. Unripe fruits fall to the ground due to the damage. In organic and non-treated orchards, the yield loss can vary between 36 and 96\% (Caruso and Cera, 2004; Rozpara et al., 2010). So far only chemical treatment is available to control this species. The insecticide application has to coincide with the petal fall of the flowers. However, at this time several bees and other beneficial insects are present in the orchard feeding on the residual flowers, which can be harmed by the insecticides. The most important aim of integrated pest management (IPM) is to spatiotemporally predict the existence of pests to determine efficient insecticide delivery timing (Lefebvre et al., 2015). So far only the chromotropic white sticky trap is available to monitor the flight activity of these two sawfly species in plum orchards (Blaisinger, 1975; Tamošiūnas et al., 2014). Although H. minuta and $H$. flava are present in Hungarian plum orchards, little is known about their populations' size, flight dynamics and distribution of the different species.

This study aimed to monitor the flight activity, species and sex ratio of Hoplocampa species during 3 years in three different locations in Hungary using chromotropic white sticky traps.

\section{MATERIAL AND METHODS}

The field trapping experiment was carried out at three different locations in Pest county, Hungary:

1. At Cegléd in the plum GenBank orchard located at the Research Institute for Fruitgrowing and Ornamentals $\left(47^{\circ} 09^{\prime} 51.2^{\prime \prime} \mathrm{N} 19^{\circ} 50^{\prime} 08.2^{\prime \prime} \mathrm{E}\right)$ in 2014 between March 27 and April 26. This orchard contains more than 200 different plum varieties with different flowering times. $P$. spinosa was not found near the orchard. During the experiment, the plum trees were not treated with any insecticide.

2. At Érd in a non-cultivated plum orchard $\left(47^{\circ} 20^{\prime} 47.7^{\prime \prime} \mathrm{N} 18^{\circ} 51^{\prime} 34.2^{\prime \prime} \mathrm{E}\right)$ in 2015 between March 31 and May 04, and 2016 between March 29 and April 22. P. spinosa may have occurred nearby this orchard, however, we did not conduct any survey on it. This orchard had no insecticide treatment. 
3. At Pomáz in a cultivated plum orchard $\left(47^{\circ} 65^{\prime} 52^{\prime \prime} \mathrm{N} 18^{\circ} 98^{\prime} 77^{\prime \prime} \mathrm{E}\right)$ in 2015 between April 0723. As far as we know P. spinosa did not exist near the orchard. During the experiment, this orchard was not treated with any pesticide.

In all three orchards, the stock of the plum trees was myrobalan plum (Prunus cerasifera). At Érd and Pomáz, besides the cultivated plant varieties, the wild type myrobalan plum was also found. This plum tree starts the flowering period a couple of days earlier compared to the cultivated varieties.

The white sticky traps (CSALOMON ${ }^{\circledR}$ PALf) were provided by Plant Protection Institute, CAR, ELRN (Budapest, Hungary) and placed out in plum orchards at the three different locations. At all locations, 4 traps were placed out. The traps were hung on the plum tree branches at $1.5 \mathrm{~m}$ above the ground. The traps were $10 \mathrm{~m}$ apart from each other. New traps were placed out at every inspection time. Traps were brought to the laboratory where the specimens were identified, sexed and counted by using a stereomicroscope. To separate H. minuta and H. fulvicornis, we used the morphological identification key published by Nagy (1960). H. minuta has 4-5 mm, while $H$. fulvicornis has a $3 \mathrm{~mm}$ body length. The whole body of $H$. minuta is black, however, the color of the clypeus, tegula and the distal part of the abdomen are brownish or yellowish of $H$. fulvicornis. $H$. minuta has a brow stigma, however, $H$. fulvicornis has a yellowish one. $H$. minuta males have yellowish-brown antennae, while $H$. fulvicornis males have a yellow one.

\section{RESULTS}

The average trap catches of the three different species varied between the experimental years and locations. In 2014, at Cegléd first adults appeared in the traps on March 27 (Fig. 1A and B) and $H$. flava was the dominant species (Fig. 1C). At this location, traps did not catch any $H$. fulvicornis. The highest trap capture of $H$. flava was on April 04, on this date the males were dominant (Fig. 1B). Interestingly, more females than males of $H$. minuta flew into the traps (Fig. 1A).

In the year 2015 at Pomáz, the trap caught the first adults on April 10 (Fig. 2A, B and C), in the same year at Érd the first adults were caught ten days earlier, on March 31 (Fig. 3C). In both locations, H. minuta was the dominant species. At Pomáz the highest trap capture of this species was recorded on April 13 (Fig. 2A); however, in the same year at Érd, the traps caught the highest number of $H$. minuta four days later on April 17 (Fig. 3A). It is important to note that both locations traps caught a third species, H. fulvicornis (Fig. 2C and 3C). Also, at both locations this year, traps captured more males than females of all three species (Fig. 2D and 3D).

In 2016 at Érd, the traps caught the first H. flava adults on March 29 (Fig. 4B). H. minuta was the most dominant species and the highest trap capture of this species' males was recorded on April 08 (Fig. 4A). On April 15, traps captured slightly more H. flava females than males (Fig. 4B). In this year, traps also caught both males and females of H. fulvicornis (Fig. 4C).

\section{DISCUSSION}

In this study, we monitored three different Hoplocampa species in three different locations of plum orchards in three consecutive years using white, sticky chromotropic traps. Because $H$. 

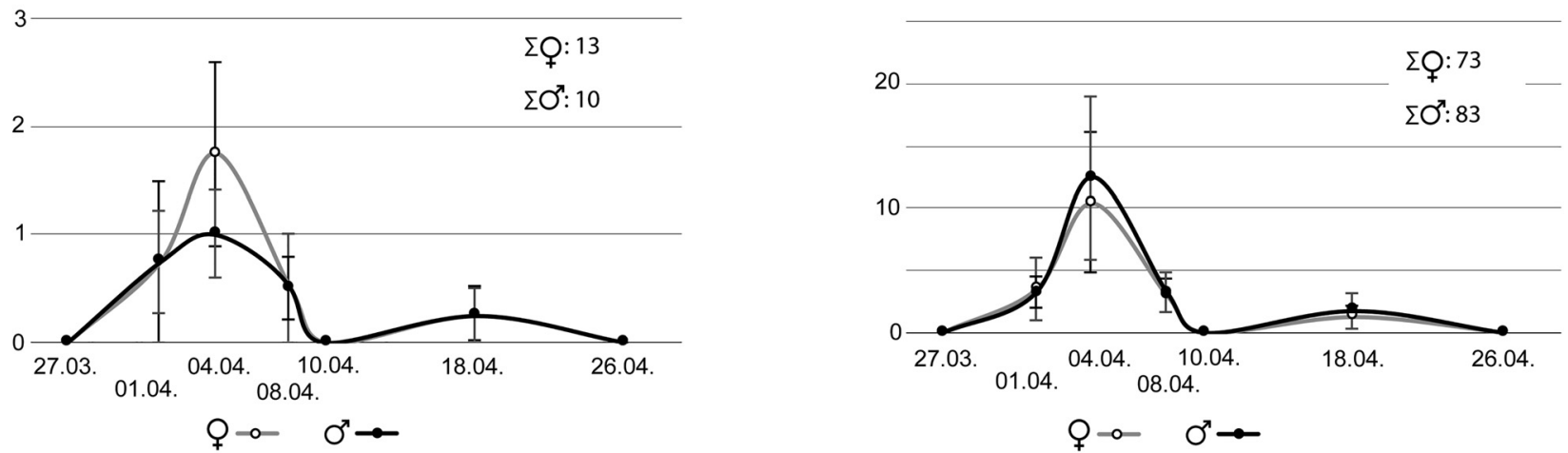

C)

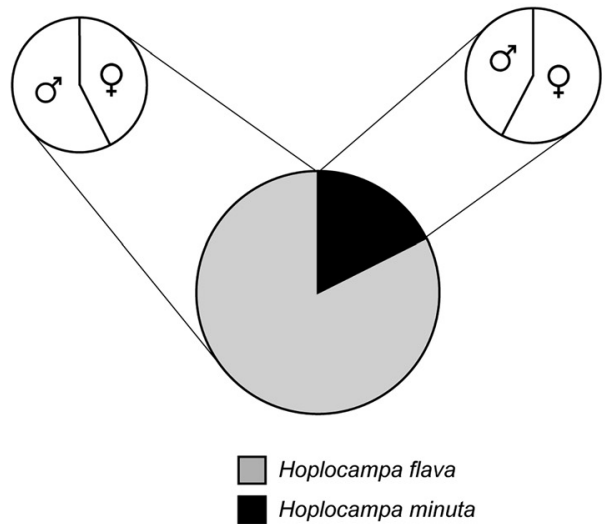

Fig. 1. Mean trap captures of H. minuta (A) and $H$. flava (B) at the inspection dates during the experiment in 2014 at Cegléd. Error bars represent the standard error of the mean. The pie chart shows the ratio of caught species and the sex ratio of each species $(\mathrm{C})$ 
A)

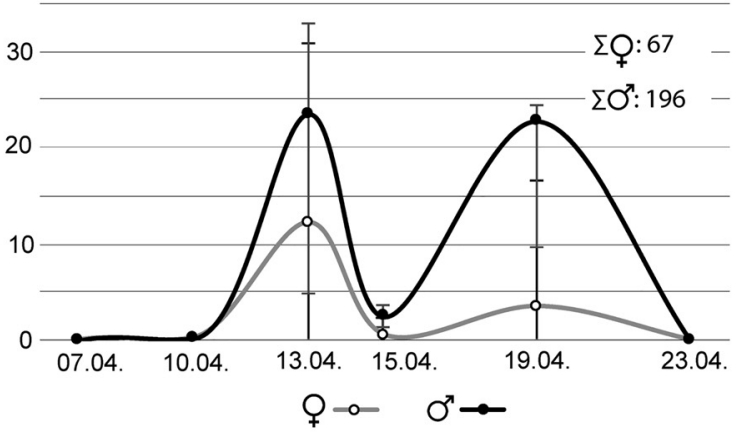

C)

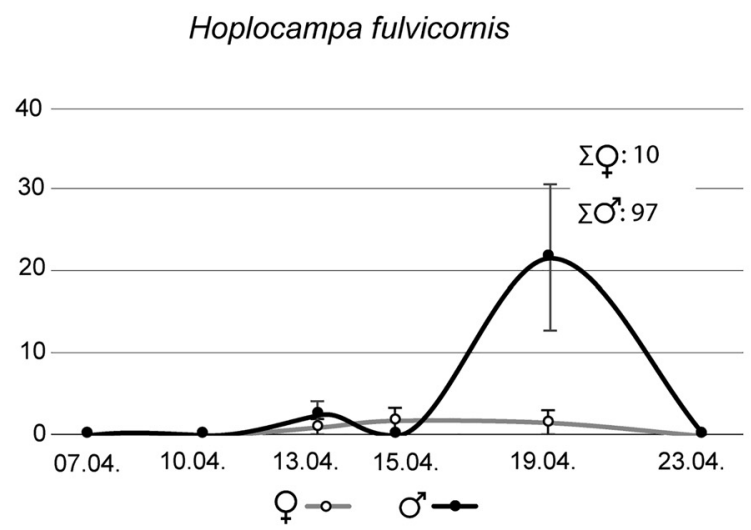

B)

Hoplocampa flava

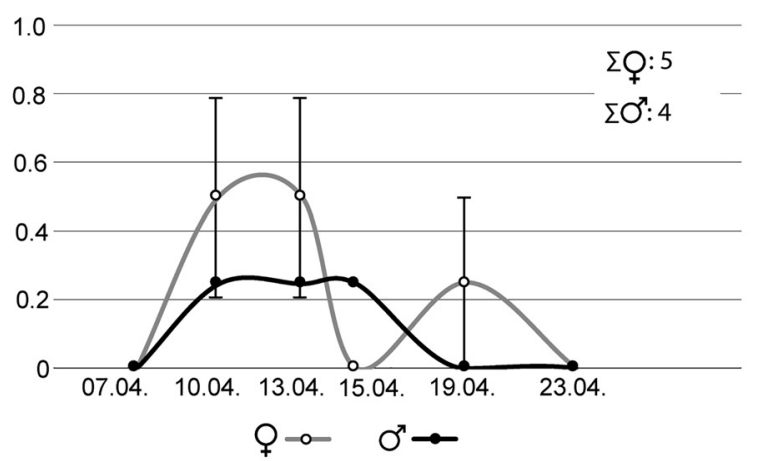

D)

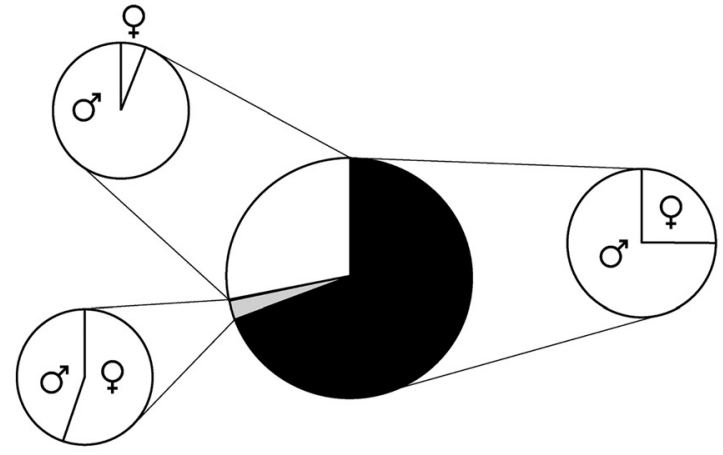

$\square$ Hoplocampa flava

Hoplocampa minuta

$\square$ Hoplocampa fulvicornis

Fig. 2. Mean trap captures of H. minuta (A), H. flava (B) and H. fulvicornis (C) at the inspection dates during the experiment in 2015 at Pomáz. Error bars represent the standard error of the mean. The pie chart shows the ratio of caught species and the sex ratio of each species (D) 


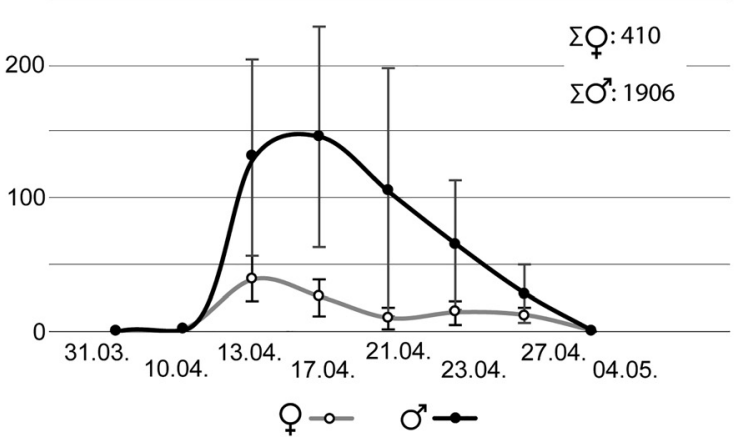

C)

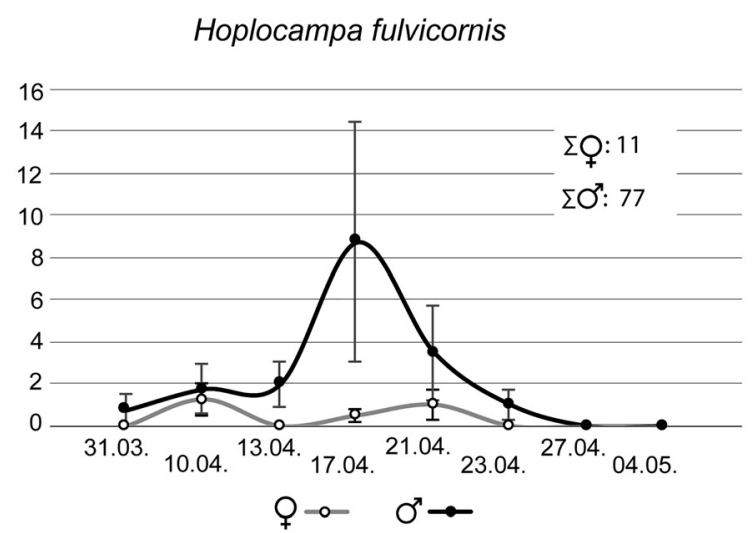

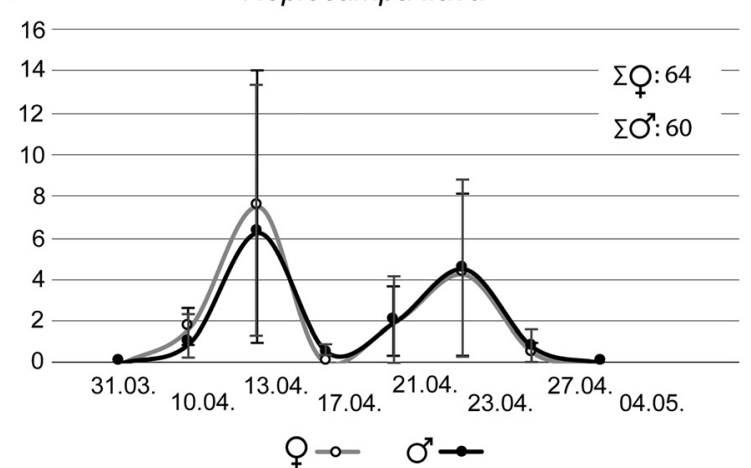

D)

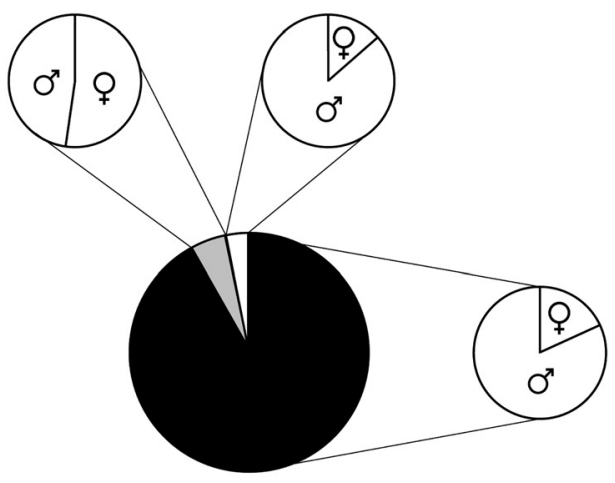

$\square$ Hoplocampa flava

Hoplocampa minuta

$\square$ Hoplocampa fulvicornis

Fig. 3. Mean trap captures of H. minuta (A), H. flava (B) and H. fulvicornis (C) at the inspection dates during the experiment in 2015 at Érd. Error bars represent the standard error of the mean. The pie chart shows the ratio of caught species and the sex ratio of each species (D) 
A)

\section{Hoplocampa minuta}

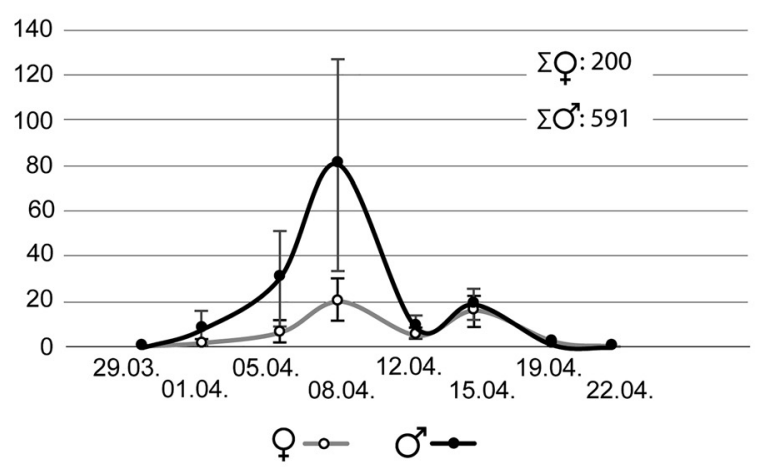

C)

Hoplocampa fulvicornis

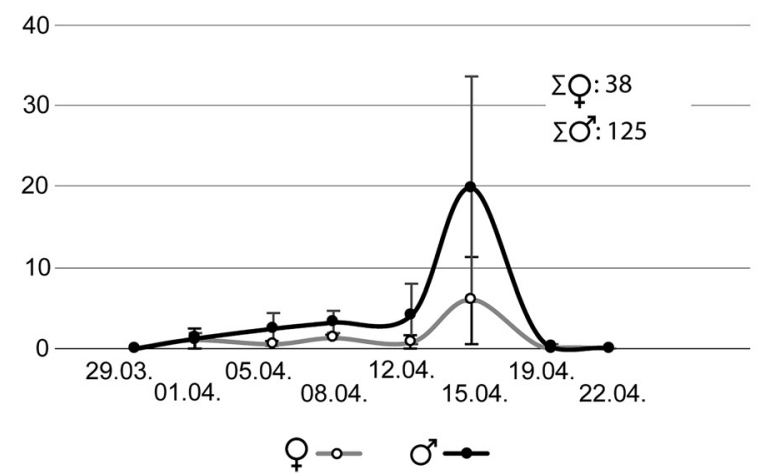

B)

Hoplocampa flava

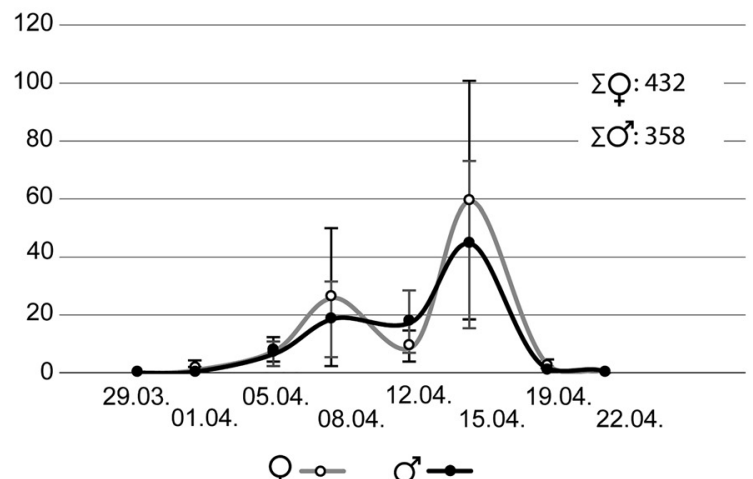

D)

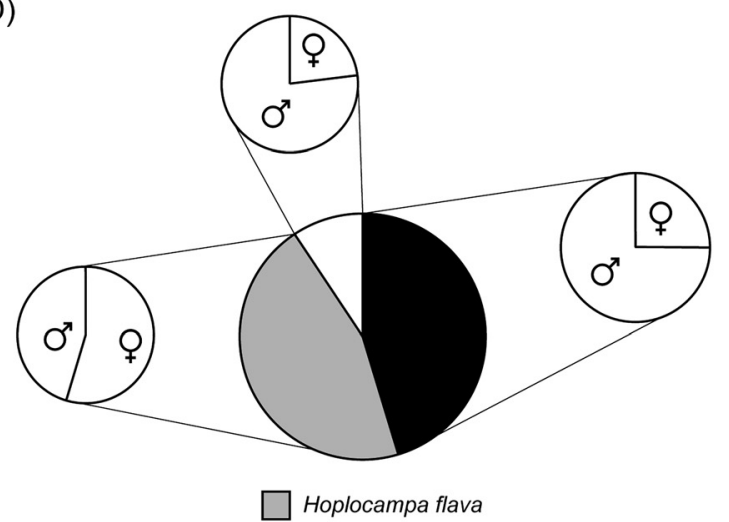

Hoplocampa minuta

$\square$ Hoplocampa fulvicornis

Fig. 4. Mean trap captures of H. minuta (A), H. flava (B) and H. fulvicornis (C) at the inspection dates during the experiment in 2016 at Érd. Error bars represent the standard error of the mean. The pie chart shows the ratio of caught species and the sex ratio of each species (D) 
minuta and $\mathrm{H}$. flava are one of the most important pest species in the plum orchards in Europe (Caruso and Cera, 2004), monitoring the population of these species is important in terms of the timing of pesticide treatments. Up to date, only the white sticky trap exists to estimate sawflies' population density in plum orchards. Neither pheromones nor feeding attractants have been identified to attract any sawfly species, which could help to monitor them.

The number of caught $H$. minuta, $H$. flava and H. fulvicornis adults in traps considerably varied between years and locations. For instance, at Érd location comparing two consecutive years the highest average trap catches varied between 146 and 80 in the case of $H$. minuta males. This could be due to the previous years' insecticide treatment, seasonal differences between years, prolonged diapause of the larvae, or larval survival rate. Tamošiūnas et al. (2014) also reported different population densities of $H$. minuta between consecutive years in the same location.

Surprisingly, the traps caught $H$. fulvicornis for the first time in plum orchards in Hungary. Although the average number of adults caught was low, however, the existence of this species in plum orchards is remarkable. $\mathrm{H}$. minuta and $\mathrm{H}$. fulvicornis are closely related species (Liston et al., 2019), the identification of these species is difficult, therefore, it might be that in earlier studies attention did not focus on the separation of these two species. The catches of $\mathrm{H}$. fulvicornis in the traps do not automatically mean that this species can cause damage to plum fruits. The larvae of this species could develop in other Prunus species' fruits and the adults could fly into the plum orchards, attracted by the white color. Pschorn-Walcher and Altenhofer (2000) show that P. spinosa is the main larval host of this species; although, this assumption was based on the adult occurrence not the larvae in the fruits. In Italy, Roberti (1948) convincingly showed that this species attacks cultivated plum varieties ( $P$. domestica and Prunus salicina). Our study did not focus on the different species' larval development in plum fruits; however, there is a high probability that this species could also damage plum fruits.

Comparing three consecutive years, the first adults were caught in 2014 on the first day of April, in 2015 at Pomáz, in the second week of April (April 10), at Érd on the last week of March and 2016 also in the last week of March. Pajač Živković et al. (2020) reported that the first $H$. minuta and H. flava adults flew at end of March in Croatia, Zagreb in 2019. However, in Lithuania, the white sticky traps caught the first $H$. minuta and $H$. flava adults one month later presumably due to the lower annual temperatures between 2010-2012 (Tamošiūnas et al., 2014). In terms of the first adult catch in the same year (Pomáz 2015, Fig. 2; Érd 2015, Fig. 3), we found 10 days differences between the locations. This could be due to the below-ground temperature differences before the first adult emergence between the locations. In the case of Hoplocampa testudinea, Zijp and Blommers (1997) found a correlation between the soil temperature and first adult emergence.

The average trap catches varied between different locations in the same year. For instance, in 2015 at Érd, on average, traps caught 6 times more H. minuta males as compared to Pomáz at the date of the highest trap catch. Most probably, this variability is caused by biological or environmental factors. Prolonged diapause could also be the reason for this phenomenon, which has been observed in H. minuta and H. testudinea populations (Tauber and Tauber, 1976; Hadzistevic, 1959; Leski, 1960). Presumably, the overwintering larval survival rate was higher at Érd compared to Pomáz, due to some biotic (parasitoids or fungal diseases) or abiotic factors (climate). For example, entomophagous fungi could cause larval mortality, which has already been reported on H. testudinea (Niezborala, 1978; Jaworska, 1992). 
In our study, males were dominant in all locations and years. Conversely, in Lithuania, Tamošiūnas et al. (2014) reported that more females than males of $H$. minuta flew into the traps. Also, in the same study, they show that the ratio of males and females of H. flava was equal.

In terms of species abundance, we found that in almost all locations and years $H$. minuta was the dominant species, except in 2014 at Cegléd, where more H. flava than other species flew into the traps. However Pajač Živković et al. (2020) showed that in Croatia H. flava was more abundant than $H$. minuta.

The data of trap catch could be used to predict the damage level caused by these species and could help in the timing of the applied insecticides. Further studies should focus on investigating the development of $H$. fulvicornis larvae in plum fruits and the correlation of blooming time and trap catches of all species in Hungary. Also, future studies could focus on pheromone and feeding attractant identification of these three Hoplocampa species.

\section{ACKNOWLEDGMENTS}

We thank Barnabás Nagy for species identification. Furthermore, we thank Zoltán Erdős and László Krasznai to provide pesticide-free experimental fields. This study was financially supported by the Marie Curie Career Integration Grant (PCIG12-GA-2012-333980) and the János Bolyai Research Scholarship of the Hungarian Academy of Sciences to ZK.

\section{REFERENCES}

Blaisinger, P. (1975). Eine auf optische Reizung basierende Fangmethode der Pflaumensägewespen Hoplocampa flava L. und H. minuta Christ. Zeitschrift für Angewandte Entomologie, 77: 353-357.

Caruso, S. and Cera, M.C. (2004). Control strategies for plum sawflies (Hoplocampa flava, Hoplocampa minuta) in organic farming. IOBC/WPRS Bulletin, 27(5): 107-111.

Hadzistevic, D. (1959). The existence of several years diapause in the plum sawflies (H. minuta and $H$. flava) in the Sarajevo region. World Congress of Agricultural Research. Rome, Italy, 1371-1376.

Jaworska, M. (1992). Biological control of Hoplocampa testudinea Klug (Hymenoptera, Tenthredinidae). Acta Phytopathologica et Entomologica Hungarica, 27: 311-315.

Lefebvre, M., Langrell, S.R.H. and Gomez-y-Paloma, S. (2015). Incentives and policies for integrated pest management in Europe: a review. Agronomy for Sustainable Development, 35(1): 27-45.

Leski, R. (1960). Studies on the bionomics of plum sawflies (H. minuta and H. flava). Rocznik nauk rolniczych, 81(2): 441-464.

Liston, A., Prous, M., and Vårdal, H. (2019). A review of West Palaearctic Hoplocampa species, focusing on Sweden (Hymenoptera, Tenthredinidae). Zootaxa, 4615(1): 1.

Nagy, B. (1960). Apfelsägewespe (H. testudinea Klug). In: Nagy, B. (Ed.) Fruit sawflies (Hoplocampa spp.). Mezőgazdasági Kiadó, Budapest, Hungary, pp. 101-117.

Niezborala, E. (1978). Studies on the biology of the apple sawfly (Hoplocampa testudinea Klug). Prace Instytutu Sadownictwa i Kwiacarstwa, Series A, 20: 201-221.

Malenovský, I., Kment, P., and Konvička, O. (2012). Species inventories of selected insect groups in the Bílé Karpaty Protected Landscape Area and Biosphere Reserve (Czech Republic). Acta Musei Moraviae/ Scientiae Biologicae, Brno: Moravian Museum. 
Pajač Živković, I., Perić, B., and Lemić, D. (2020). Yellow and black plum sawfly population in the orchard "Maksimir". Fragmenta phytomedica, 34(5): 32-39.

Pschorn-Walcher, H. and Altenhofer, E. (2000). Langjährige Larvenaufsammlungen und Zuchten von Pflanzenwespen (Hymenoptera, Symphyta) in Mitteleuropa. Linzer Biologische Beitraege, 32(1): 273327.

Roberti, D. (1948). Le Oplocampe del Susino II. Hoplocampa rutilicornis Klug. Bolletino del Laboratorio di Entomologia Agraria "Filippo Silvestri" Portici, 9: 8-26.

Rozpara, E., Badowska-Czubik, T., and Kowalska, J. (2010). Problems of the plum and cherry plants protection in ecological orchard. Journal of Research and Applications in Agricultural Engineering, 55(4): 73-75.

Tamošiūnas, R., Valiuškaite, A., Survilienė, E., and Rasiukevičiūtè, N. (2014). Species ratio, spring emergence, population dynamics and damage of plum sawflies Hoplocampa minuta and H. flava in plum orchard. Zemdirbyste-Agriculture, 101(1): 91-100.

Tauber, M.J. and Tauber, C.A. (1976). Insect seasonality: diapause maintenance, termination, and postdiapause development. Annual Review of Entomology, 21: 81-107.

Zijp, J.P. and Blommers, L.H.M. (1997). Prediction of flight of apple sawfly, Hoplocampa testudinea, using temperature sums. Entomologia Experimentalis et Applicata, 84: 71-75.

Open Access. This is an open-access article distributed under the terms of the Creative Commons Attribution 4.0 International License (https://creativecommons.org/licenses/by/4.0/), which permits unrestricted use, distribution, and reproduction in any medium, provided the original author and source are credited, a link to the CC License is provided, and changes - if any - are indicated. (SID_1) 